\title{
THE EFFECTS OF COVID-19 ON INTERNATIONAL CONTRACTS: A COMPARATIVE OVERVIEW
}

\author{
Laura Maria Franciosi*
}

This article provides a timely consideration of the effect of COVID-19, and legislative measures taken to deal with it, on contractual liabilities. The relationship of COVID-19 events to the defences of force majeure and hardship are investigated by comparative analyses of several countries' laws as well as the issue whether the national lockdown measures can be qualified as "overriding mandatory provisions". The study is of both domestic contracts and international commercial contracts.

\section{INTRODUCTION}

Every contract can be interested in supervening events which affect the possibility for a party to perform their contractual obligations, or significantly alter the equilibrium of the contract. Generally every legal system provides for the legal consequences of such events, and the relevant legal framework is conceived to preserve the binding effect of the pacta sunt servanda rule. ${ }^{1}$ Accordingly, all legal systems require the supervening event to fulfil specific requirements, and the mere fact that the performance of the contractual obligation becomes more difficult or burdensome or expensive is not enough to discharge the contractual party and to release them from liability. In particular, within the international context of business relations a distinction is generally made between force majeure - where the supervening event renders the performance impossible or extremely difficult to execute (whether definitively or temporarily, totally or partially) - and hardship, where the occurrence fundamentally alters the equilibrium of the contract either because the cost of a party's performance has increased or because the value of the performance a party receives has diminished. ${ }^{2}$

* Assistant Professor of Comparative Law, University of Bologna; LLM, Louisiana State University; PhD, University of Milan.

1 "Agreements must be kept."

2 See in particular arts 6.2.1 and 7.1.7 of the International Institute for the Unification of Private Law (UNIDROIT) UNIDROIT Principles of International Commercial Contracts 2016 [UNIDROIT Principles], as well as the relevant model clauses drafted by the International Chamber of Commerce (ICC), as further detailed in Part III below. Indeed, both the UNIDROIT Principles and the model clauses for international 
Currently, the whole world is dealing with the effects of the COVID-19 outbreak and with the consequences of governmental provisions aimed at preventing its dissemination, which include lockdown and containment measures. This phenomenon affects international contracts, in particular within the context of business relationships. ${ }^{3}$ Indeed, COVID-19 has been universally deemed to be an act of God, and the governmental regulations enacted to prevent its spreading have been deemed to be an act of King (or factum principis). For example, since January 2020 the China Council for the Promotion of International Trade has issued more than 5600 certificates attesting force majeure on behalf of companies that have failed to comply with the obligations of international contracts, allegedly due to COVID-19. In India, an Office Memorandum of the Ministry of Finance dated February 192020 has declared that the disruption of the supply chain as a result of the COVID-19 outbreak constitutes a force majeure event. In particular, the Memorandum clarifies that COVID-19 should be considered "a case of natural calamity". In Italy, Tribunals of first instance have issued temporary injunctions on behalf of debtors who fail to pay the rent in a commercial lease contract due to the effect of the lockdown measures, thus preventing the creditor from executing the provided collateral.

However, as argued in this article, this is not enough in itself to excuse the non-performing party, or to alter the original terms of the contract, especially within an international business context. With particular reference to such field, COVID-19 and the related governmental provisions raise a specific issue: in the case of international commercial transactions, the probability that unforeseen events affecting the performance of a party will arise is much higher than in the case of national contracts, where both parties are subject to the same domestic legal and economic order. ${ }^{4}$ This is because the performance of international contracts involves additional risks, and the legal and political framework of international commercial contracts is in general less stable than that of national contracts. ${ }^{5}$

contracts, for example those drafted by the ICC, devote particular attention to the topic of supervening events. Regardless of the names of the legal doctrines adopted, many national legal systems distinguish between force majeure and hardship too, while others deal with the issue of supervening events without distinguishing between the impossibility to perform and performance being excessively burdensome. Since it is often not so easy to distinguish between an event falling within the conceptual category of force majeure rather than hardship, both the UNIDROIT Principles and the ICC model clauses adopt a functional approach mandating that it is up to the party invoking the supervening event as an excuse for their non-performance to qualify it as force majeure or hardship. Generally, the choice is grounded in light of the available remedies. The United Nations Convention on Contracts for the International Sale of Goods 1489 UNTS 583 (opened for signature 11 April 1980, entered into force 1 January 1988) [CISG], rather, opts in favour of a functional approach, as discussed in Part III below.

3 The present analysis will exclusively deal with international B2B contracts.

4 Christoph Brunner Force Majeure and Hardship Under General Contract Principles (Kluwer Law International, Alphen aan den Rijn (The Netherlands), 2009) at 1.

5 At 1 . 
Consequently, in order to properly assess the legal effects of COVID-19 and the related governmental provisions on international contracts, it is important to look at the three pillars of every international contract, namely:

(i) the content of the contract, its clauses and their wording;

(ii) the governing law; and

(iii) who is entitled to resolve a dispute.

From an operative point of view, the third pillar raises an issue to be dealt with before referring to the other two pillars. Accordingly, such topic will be addressed in Part II of the present article, while the first and second pillars, which constitute the substantial law of the international contract, will be jointly addressed in Part III. In particular, Part III will compare different legal systems, model clauses and international legal instruments of contract law (either binding or "soft law") about the legal effects of supervening events, like COVID-19 and its related statutory provisions. Indeed, in spite of the specific features of each system, the comparison reveals a common core of rules and concerns. ${ }^{6}$ Finally, Part IV will focus on a specific issue of the international contracts, namely whether the national legislative provisions waiving non-performing parties from their contractual liabilities due to the COVID-19 outbreak, can be deemed as "overriding mandatory provisions" to be applied to the international contract regardless a different governing law. This is important in order to assess the legal effects of national certificates or public provisions qualifying COVID-19 and lockdown measures as force majeure events.

\section{THE RELEVANCE OF WHO IS ENTITLED TO RESOLVE A DISPUTE}

With reference to international business contracts, identifying who will be entitled to resolve a dispute (ie whether a national judge or an arbitral tribunal) matters for three main reasons

First, because it might be helpful in order to determine the law applicable to the international contract, in the event of no choice by the parties. Indeed, should the dispute be solved through arbitration, the arbitral tribunal is entitled pursuant to art 28(2) of the UNCITRAL Model Law on International Commercial Arbitration ${ }^{7}$ and art 21(1) of the ICC Arbitration Rules 2017, ${ }^{8}$ to set the

6 See below $\mathrm{n} 24$

7 UNCITRAL Model Law on International Commercial Arbitration 1985, With amendments as adopted in 2006 (UN Doc A/40/17 annex I and A/61/17 annex II, 7 July 2006) [UNCITRAL Model Law], art 28(2): "Failing any designation by the parties, the arbitral tribunal shall apply the law determined by the conflict of laws rules which it considers applicable."

8 Article 21(1):

The parties shall be free to agree upon the rules of law to be applied by the arbitral tribunal to the merits of the dispute. In the absence of any such agreement, the arbitral tribunal shall apply the rules of law which it determines to be appropriate. 
governing law. In the first case, it will be through a two-step mechanism: firstly, the arbitral tribunal shall identify the conflict of law rules better fitting for the purposes of that contract and then, through their application, it will point out the governing law. In the second case, the arbitral tribunal will have the power to immediately determine the governing law for that international contract, which may even be the new Lex Mercatoria ${ }^{9}$ combined with the UNIDROIT Principles on their own. In case of litigation, absent a choice of law clause, the national judge will have to apply the rules of its lex fori (ie its conflict of law rules) in order to determine the governing law of the international contract. ${ }^{10}$ Consequently, the analysis in question might be determinant for the outcome of the dispute in the case both of arbitration and litigation. ${ }^{11}$

Secondly, identifying who will have to solve the dispute is significant in order to assess the cultural matrix of the judge or arbitrator(s), because this element, in addition to other legal formants, affects the interpretation and application of the rules about supervening events. ${ }^{12}$ The cultural environment, as well as other related factors, indeed, influence the attitude towards the law and its application. ${ }^{13}$ Among others, examples of such phenomenon are:

9 "Merchant law."

10 For example, in the event of a contract between EU parties, the EU national judge shall apply the provisions of Regulation (EC) No 593/2008 of the European Parliament and of the Council of 17 June 2008 on the law applicable to contractual obligations [2008] OJ L177/6 [Rome I Regulation].

11 See for example Luiz Gustavo Meira Moser "Parties' preferences in international sales contracts: an empirical analysis of the choice of law" (2015) 20 Unif L Rev 19 (carrying out an empirical survey about the choice of law and its interactions with litigation and/or arbitration).

12 See in particular the seminal remarks of Alan Watson "From Legal Transplants to Legal Formants" (1995) 43 Am J Comp L 469 (emphasising how culture determines the parameters of the judicial legal reasoning, the systems of law that jurists would borrow from and even the extent to which they would borrow, as well as how such approach determines the standing of each individual within the culture. Also arguing how the nature of this culture varies from one society to another, and concluding that unless one has an awareness of the importance of this rootedness in a particular legal culture, one can never understand the parameters of legal debate); and Rodolfo Sacco "Legal Formants: A Dynamic Approach to Comparative Law" (1991) 39 Am J Comp L 1 (highlighting that the primary purpose of comparative law is the acquisition of knowledge and that, in order to gain a proper knowledge of a legal system, the connected "legal formants" must be considered. In particular, legal formants are those elements concurring to characterise a particular legal system. Examples are, in addition to legislative provisions, court rulings, academic writing, professional and administrative practice developed in a particular context).

13 The comparative law devotes peculiar attention to these elements. The "Trento thesis" - ie the manifesto of Italian comparatists - stresses the importance of considering the operational rules rather than the theoretical statements, as well as the effect of hidden factors (ie crittotipi) affecting the interpretation and application of the rule of law. See in particular Rodolfo Sacco Introduzione al Diritto Comparato (UTET Torino, Turin (Italy), 1992) 16, n 32 and 67-70; and Josef Esser Vorverständis und Methodenwahl in der Rechtsfindung (Athenaum Fischer Taschenbuch Verlag, Frankfurt, 1972). 
(i) the traditional disinclination of common law courts towards the duty of good faith as well as any precontractual liabilities, while the civil law systems give special relevance to good faith and its applications, ${ }^{14}$ and

(ii) the clear disfavour of English courts towards consumer claims in cases of misleading advertising. ${ }^{15}$

14 For an analysis of such an opposite approach and its effect on the drafting of the CISG (which does not include a specific duty of good faith and fair dealing) see Michael Bridge "Good Faith, the Common Law, and the CISG" (2017) 22 Unif L Rev 98 at 98, arguing in particular that:

It is a notorious fact that one of the pressure points emerging when the common law and the civil law are set against each other lies in their differing attitudes to the notion of good faith. This was a matter of some significance during the evolution of the Convention on Contracts for the International Sale of Goods (CISG).

See also Ingeborg Schwenzer "Global Unification of Contract Law" (2016) 21 Unif L Rev 60 at 67 (noting that: "The frequent use of good faith [ie within the UNIDROIT Principles] is hardly acceptable to many common law lawyers.") As is known, common law courts do not recognise the precontractual duty of good faith: see Walford v Miles [1992] 2 AC 128 (HL) at 138: "the concept of a duty to carry on negotiations in good faith is inherently repugnant to the adversarial position of the parties when involved in negotiations ... A duty to negotiate in good faith is as unworkable in practice as it is inherently inconsistent with the position of a negotiating party"). Within the United States' legal system, the doctrine of "promissory estoppel", set forth in $\S 90$ of American Law Institute Restatement (Second) of the Law of Contract (2nd ed, St Paul, Minnesota, 1981), has been referred to in order to sanction outrageous behaviour during negotiations (for instance Hoffman v Red Owl Stores, Inc 26 Wis 2d 683 (1965)), though the precedent has had limited application. However, even within such legal system, a general recognition of the precontractual duty of good faith is lacking. Common law courts tend to recognise the legal effects of the duty of good faith if undertaken within a precontractual agreement and supported by the consideration and the intent to be bound: see E Allan Farnsworth "Precontractual Liability and Preliminary Agreements: Fair Dealing and Failed Negotiations" (1987) 87 Colum L Rev 217; and Bridge, above n 14, at 106. On the contrary, the civil law systems recognise the precontractual duty of good faith: see for example arts 1337 and 1338 of the Italian Civil Code (cc) and the new $\S 311$ of the Bürgerliches Gesetzbuch (BGB) which, following the 2002 legislative reform, has codified the culpa in contrahendo doctrine. Before the 2002 reform, the German courts dealt with precontractual liability cases through the $\S 242$ of the BGB (Treu und Glauben). Though the French Civil Code did not specifically encompass the precontractual duty of good faith, the French courts used to affirm it. Currently, through the 2016 legislative reform, such duty has been expressly recognised in the new version of art 1104 of the Civil Code, which provides "Les contrats doivent être négociés, formés et exécutés de bonne foi. Cette disposition est d'ordre public" ("contracts must be negotiated, made, and executed in good faith. This requirement is a matter of public policy").

15 Such directive amended the Directive 84/450/EEC [1984] OJ L250/17 and has been subsequently abrogated by the Directive 2005/29/EC of the European Parliament and of the Council of 11 May 2005 concerning unfair business-to-consumer commercial practices in the internal market and amending Council Directive 84/450/EEC, Directives 97/7/EC, 98/27/EC and 2002/65/EC of the European Parliament and of the Council and Regulation (EC) No 2006/2004 of the European Parliament and of the Council [2005] OJ L149/22. Currently the matter is ruled by the Directive 2006/114/EC of the European Parliament and of the Council of 12 December 2006 concerning misleading and comparative advertising [2006] OJ L376/21. 
Indeed, English courts tended to decline them on the basis of the "smart-consumer" criterion while, on the contrary, French courts showed a manifest paternalistic approach to protect the naive and unsophisticated consumer to the extent that - even after the enactment of Directive 97/55/EC on comparative and misleading advertising, whereby the common standard of the "reasonable consumer" has been adopted - the two opposite tendencies persisted. ${ }^{16}$

Furthermore, the relevance of the cultural matrix is one of the main concerns when dealing with the interpretation and application of the United Nations Convention on Contracts for the International Sale of Goods (CISG). The Convention specifically affirms the autonomous meaning of its provisions and the need for their uniform interpretation. ${ }^{17}$ However, absent an international court aimed at ensuring the CISG is interpreted the same way in the adhering countries (like the European Court of Justice with the EU law), the task is left to national judges, to arbitrators and to the doctrinal formant. ${ }^{18}$ Although a pre-eminent role is played by scholars and private institutions (for example the CISG Advisory Council) ${ }^{19}$ in order to ensure the uniform interpretation of the CISG, certain inconsistencies due to the influence of national factors still endure..$^{20}$

Thirdly, the identification of who will have to resolve the dispute plays a role in the possible application to the international contract of the so-called "overriding mandatory provisions" of a particular legal system, in spite of the applicable law for that contract. This topic is addressed below in Part IV.

16 Directive 97/55/EC of European Parliament and of the Council of 6 October 1997 amending Directive 84/450/EEC concerning misleading advertising so as to include comparative advertising [1997] OJ L290/18. For the different approaches by English and French courts see Charlotte J Romano "Comparative Advertising in the United States and in France" (2005) 25 Nw J Int'l L \& Bus 371.

17 CISG, above $\mathrm{n} 2$, art 7(1).

18 See for example John Honnold "The Sales Convention in Action - Uniform International Words: Uniform Application?" (1988) 8 J L \& Comm 207; and Franco Ferrari "Do Courts Interpret CISG Uniformly?" in Quo Vadis CISG? (Sellier European Law Publishers, Brussels, 2005) at 3 and following, in particular 13-14, highlighting the fundamental role of international online CISG databases, for example CLOUT, Unilex, Pace Database on the CISG and International Commercial Law and CISG-online.

19 The CISG-AC is a private initiative which aims at promoting a uniform interpretation of the CISG. See further CISG-AG <www.cisgac.com>.

20 See Ingeborg Schwenzer "National Preconceptions that Endanger Uniformity" (2007) 19 Pace Int'l L Rev 103 (referring in particular to the inconsistencies in the interpretation of CISG, art 39(1), in regard to "reasonable time" to notify the seller about the non-conformity of the goods). 


\section{THE "COMMON CORE" OF THE LEGAL EFFECTS OF BOTH COVID-19 AND THE RELATED GOVERNMENTAL PROVISIONS}

In international business relationships, the autonomy of contracting parties has a fundamental role. Parties are entitled to create new contracts and to tailor the content of contracts, typical or atypical, to their needs through specific clauses and a proper drafting. However, the legal effects of such legal framework should be scrutinised in light of the governing law of the international contract, ${ }^{21}$ whether expressly set forth by the parties or pointed out through the mechanisms mentioned in Part II above. Thus, the contractual provisions and the governing law are strictly intertwined in order to delineate the substantial law of the international contract. With regard to COVID-19 and the related governmental provisions, it must be firstly verified whether the parties have specifically addressed the legal effects of a supervening event through a force majeure or a "hardship" clause, or through both. Indeed, every legal system recognises the role of parties' autonomy in setting forth the legal regime and the consequences of such events. If the contract includes one or both of the abovementioned clauses, the concern will be to properly analyse their content to verify whether an event like COVID-19 and its consequences have been provided for, and to what extent. ${ }^{22}$

With regard to the governing law of the contract, it must be emphasised that every legal system has addressed the issue of the legal effects of supervening events on contracts. ${ }^{23}$ In some cases, distinguishing between impossibility of performance (force majeure) and events significantly altering

21 A common example is that of penalty clauses. Such clauses are null and void in common law (which, on the contrary, allows liquidated damage clauses), while they are admitted in many civil law systems.

22 See in particular Yves Derains "Foreword" in Fabio Bortolotti and Dorothy Ufot (eds) Hardship and Force Majeure in International Commercial Contracts: Dealing with unforeseen events in a changing world (ICC, Paris, 2018) 5 at 6:

In international contractual practice, force majeure is too often left to boilerplate clauses with lists of events ... which raise difficult problems of interpretation ... This difficulty is increased when the law applicable to the contract is not very familiar with the legal concept of force majeure ... Although they are an avatar of the rebus sic stantibus clause, hardship clauses are relatively new since they started to play a significant role in contractual practice in the last part of the 20th century. ... The above remarks show the practical importance of force majeure and hardship clauses. The effect on the performance of international contracts of the imposition of economic sanctions, which may be characterized as force majeure events or hardship according to the circumstances, is, among others, an illustration of this importance.

23 When the legislative formant has not expressly addressed the issue of unexpected change of circumstances, the task to deal with the consequences of such occurrence has been up to the courts. An example is the Spanish legal system where, absent an express legislative provision for the supervening change of circumstance, the issue has been dealt with by the courts: see Jorge C Jerez "The Unexpected Change of Circumstances Under American and Spanish Contract Law" (2017) 25 Eur Rev Priv L 909 at 912, arguing that courts have ruled such cases either adopting foreign solutions or alleging the doctrine of clausula rebus sic stantibus, which is not expressly included in the Spanish Civil Code. 
the contractual equilibrium though the performance is still possible ("hardship"); in other cases, providing for an unitarian doctrine. As will be highlighted in this Part, in spite of the specificities of each legal system, a common core of rules can be discerned. ${ }^{24}$ In addition, the interaction among legal systems, international legal instruments and model clauses reveals a common tendency towards certain solutions as well.

As is generally known, in older common law once a contract had been made, the parties were absolutely bound and remained committed even if a change in circumstances made it extremely difficult or even impossible for one of them to perform. ${ }^{25}$ By the mid-19th century, the harshness of the rule was mitigated by the judicial recognition of the doctrine of "impossibility of performance". In its original form, as depicted by the English case Taylor $v$ Caldwell, ${ }^{26}$ the doctrine was quite narrow. If, when making the contract, the parties reasonably contemplated that its performance was dependent on the continued existence of a person or a thing, the death of the person or the destruction of the thing, not caused by the fault of the party seeking relief, would excuse performance by that party and would result in the termination of the contract without liability for breach. ${ }^{27}$ Accordingly, in its original form the doctrine was limited to situations in which the change of circumstances made the contract objectively impossible to perform. Subsequently, English Courts, through an adaptation of the impossibility defence, developed the doctrine of frustration in the famous "Coronation case": Krell v Henry. ${ }^{28}$

However, it must be noted that the doctrine of frustration has always been construed narrowly by the courts of common law countries. The analysis of such precedents reveals an inclination towards the pacta sunt servanda rule, as well as judicial disfavour of any mechanisms aimed at allowing the

24 The expression purposely evokes "The Common Core of European Private Law Project", although the present comparative analysis is not exclusively focused on European legal systems. This project was launched in 1993 at the University of Trento under the auspices of the late Professor Rudolf B Schlesinger. The aim of this collective scholarly enterprise is to unearth what is already common to the legal systems of European Union member states, but not with the specific purpose of their unification. For further information about the project see: The Common Core of European Private Law series published by the Cambridge University Press.

25 Paradine v Jane (1647) Aleyn 26, 82 ER 897 (KB).

26 Taylor v Caldwell (1863) 3 B \& S 826, 122 ER 309 (QB).

27 See in particular E Allan Farnsworth, William F Young and Carol Sanger Contracts: Cases and Materials (6th ed, Foundation Press, New York, 2001) 785 and following and 801-813.

28 Krell v Henry (1903) 2 KB 740 which involved the rental of a flat to assist at the King's coronation parade Although the contract did not expressly mention the purpose of the rental, both parties understood that the sole purpose in making it was to view the coronation procession. This purpose was the very foundation of the contract. The postponement of the parade due to the illness of the King was a supervening event depriving the contract of such foundation, and that was not reasonably considered by the parties when entering into their contract. Consequently, although the event did not render the performance impossible, it so defeated the purpose of the contract that it should excuse the defendant. 
party to be discharged from their contractual obligations and from liability. ${ }^{29}$ This is particularly true in case of lease agreements. ${ }^{30}$ An example of such approach, which is pertinent to the current issue of COVID-19, can be found in a 2004 case decided by the Hong Kong District Court. ${ }^{31}$ The Court found that the outbreak of severe acute respiratory syndrome (SARS) did not frustrate a contract in the landlord and tenant context. In that case, there had been an outbreak of SARS in the tenant's building. The tenant argued that the agreement was frustrated because of a 10 day isolation order against the premises. The Court held that 10 days was an insignificant amount of time compared to the overall duration of the contract (ie two years), and that the supervening event did not significantly alter the contractual obligations of the parties. In the opinion of the Court, although SARS might be qualified as an "unforeseeable event" potentially affecting the contract, nevertheless, in the dispute at stake, it had not prejudiced the contractual relationship. Therefore, the tenant's claim was rejected and the tenant was ordered to comply with the original terms of the contract. ${ }^{32}$

Within the United States legal system, pursuant to Uniform Commercial Code §2-615, a party's failure to perform may be excused by subsequent impracticability if the affected party proves that: the parties entered the contract on the basic assumption that an event would not occur; the event occurred; the event made performance impracticable (thus not merely more expensive); the affected party was not at fault for the impracticability; and the same party did not agree to perform despite the occurrence of the event. While the UCC does not contemplate frustration, the Restatement (Second) of the Law of Contract provides for both such legal doctrines (in $\S 261$ and following for impracticability and $\S$ 265 for frustration). A party's failure to perform may be excused by subsequent frustration if the affected party proves: the parties entered the contract on the basic assumption that an event would not occur; the event occurred; the event substantially frustrated the party's primary purpose for entering the contract; the affected party was not at fault for the frustration; and the party did not agree to perform despite the occurrence of the event. In addition, temporary impracticability or frustration suspends the duty to perform, but does not automatically discharge it. ${ }^{33}$ Partial impracticability does

29 For an interesting perspective on the allocation of contractual risk see Richard Posner and Andrew M Rosenfield "Impossibility and Related Doctrines in Contract Law: An Economic Analysis" (1977) 6 JLS 83.

30 It was not till 1981, the House of Lords admitted, in principle, the applicability of the doctrine of frustration to lease contracts, but only in exceptional cases (however, declining its application in the case at stake). See National Carriers Ltd v Panalpina (Northern) Ltd [1981] AC 675 (HL).

31 Li Ching Wing v Xuan Yi Xiong [2004] 1 HKC 353 (DC).

32 The described strict approach has been confirmed by a subsequent case Huen Wai Kei v Choy Kwong Wa Christopher [2013] HKEC 819 (CFI), cited in Gordon Chung "A Comparative Analysis of the Frustration Rule: Possibility of Reconciliation between Hong Kong-English 'Hands-off Approach' and German 'Interventionist Mechanism'" (2017) 25 Euro Rev Priv L 109 at 118 (arguing in particular that the Hong Kong Courts "have shared the same sense of scepticism toward [frustration of purpose]" as English Courts, therefore adopting a narrow application of the defence, particularly in the commercial context).

33 See Restatement, above n 14, § 269. 
not discharge performance of other duties if substantial performance remains practicable or the other party agrees to perform in full despite receiving only partial performance. ${ }^{34}$

It must be highlighted that UCC $\S 2-615$ specifically refers to the seller. However, for contracts in general, reference shall be made to the traditional common law doctrine and the Restatement has been deemed an expression of the latter. Consequently, the doctrine of impracticability as set forth in $\S 261$ and following of the Restatement can be applied.

However, United States courts have applied both commercial impracticability and frustration quite narrowly. ${ }^{35}$ Such approach is consistent with the Introductory Note to ch 11 of the Restatement, that affirms the binding force of contractual terms:

Contract liability is strict liability. It is an accepted maxim that pacta sunt servanda, contracts are to be

kept. The obligor is therefore liable in damages for breach of contract even if he is without fault and even

if circumstances have made the contract more burdensome or less desirable than he had anticipated.

With reference to the legal effects of supervening events, the Italian system distinguishes between impossibility of performance on one side (arts 1463-1466 of the Italian Civil Code or cc), and the case of performance becoming excessively burdensome (eccessiva onerosità sopravvenuta) on the other, which is dealt with in arts $1467-1468 \mathrm{cc} .{ }^{36}$ Although the latter does not completely overlap with the general concept of hardship, the aim of both doctrines is to provide the affected party with a remedy, should the performance become excessively burdensome after the contract has been entered into. The requirements in art $1467 \mathrm{cc}$ are: at least one of the performances must not have been completely executed; the performance shall be excessively burdensome (when compared to the normal range of risk); $; 7$ and the onerousness shall be due to extraordinary and unpredictable events. If such requirements are met, the affected party is entitled to ask the judge to terminate the contract. To avoid the termination of the contract, the counterparty may propose (but is not obliged) to modify

34 Restatement, above $\mathrm{n} 14, \S 270$.

35 See for example Claude D Rohwer and Anthony M Skrocki Contracts in a Nutshell (St Paul, Minnesota, 2000) at 341-342 (arguing that phenomena that occurred after the official drafting of the Restatement and the enactment of the Uniform Commercial Code, including oil embargoes by exporting nations, closure of canals and a worldwide shortage of raw materials, produced litigation that gave the courts the opportunity to move into new areas in the subject of impracticability or frustration; and highlighting that: "The resulting case law has not been as liberal in excusing performance as might have been anticipated").

36 Article $1467 \mathrm{cc}$ applies to contracts in general. However, the Italian Civil Code provides also for specific applications of the rule in the case of insurance contracts (see arts 1897-1898 cc) and building contracts (art $1667 \mathrm{cc})$.

37 The Italian courts, however, grant the remedy even in cases where the party complains that, while the value of their performance is unvaried, on the contrary the value of the counter-performance has been excessively devalued. See Vincenzo Roppo "Il Contratto" in Giovanni Iudica and Paolo Zatti (eds) Trattato di Diritto Privato (Giuffrè Editore, Milan, 2001) 1015 at 1021-1022 (referring to such phenomenon as "indirect onerousness"). 
the terms of the contract in order to restore the equity of the bargain. However, the judge has no power to alter the terms of the contract, nor is the affected party entitled to require the renegotiation of the terms.

On the other side, in the event of impossibility of performance due to a force majeure event, the affected party is released from liability if that party is not in default. The contract is terminated and both parties are discharged from their obligations (had one party performed, the performance must be returned). When only partial performance is possible, it is up to the counterparty to decide whether that party is interested in receiving it or not; in case of acceptance of the partial performance, the counterparty's performance is proportionally reduced. In the event of temporary impossibility, the affected party is not liable for the delay in performing. However, if the impossibility persists, the contract is terminated if, according to the nature of the performance or to the legal ground of the obligation, the affected party cannot be held to be still obliged to perform, or the counterparty is no longer interested in receiving it. ${ }^{38}$

However, if parties provide for such events through ad hoc force majeure and/or hardship clauses, the will of the parties prevails and the judicial scrutiny will be limited by such clauses. Absent any of them, the above-mentioned legal framework will rule.

With reference to COVID-19, there have been interesting holdings of Italian first instance courts, dealing with commercial leases. In particular, the common issue of such cases deals with the harshness of the duty to pay the agreed rent whilst the lockdown measures are in effect. In a first case, the Tribunal of Venice found in favour of the lessees of a clothing store within a mall which was closed due to the epidemic and the relevant lockdown measures who had not paid rent from February to April, amounting to 50,000 €. The lessee claimed that the lessor was not entitled to enforce the collateral granted by the bank. The Tribunal issued a temporary order on behalf of the debtor, preventing the creditor from enforcing the collateral. The issue whether the breach of contract was excusable or not was referred to a full hearing and has not been decided yet. However, the granting of the temporary relief on behalf of the lessee in light of the current situation is significant. ${ }^{39}$ The same issue has been addressed by the Tribunal of Bologna. ${ }^{40}$ In this case the lessee was the owner of a beauty salon subject to the lockdown, who had provided bank collateral as a guarantee of the regular

38 Temporary impossibility is dealt with in art $1256 \mathrm{cc}$, in the chapter devoted to "obligations" in general. Nevertheless, it is commonly deemed applicable to contracts too: Rodolfo Sacco and Giorgio De Nova $\mathrm{Il}$ Contratto (4th ed, UTET, Turin, 2016) at 1669 and following.

39 Tribunal of Venice, decree of 22 May 2020. The legal provision referred to by the Tribunal in order to find for the debtor - art 3, para 6-bis of the Italian Law Decree n 6, 23.02.2020 (the "stay at home" law), then converted in Law Decree n 13, 5.03.2020 - provides that the compliance with the lockdown measures shall be always taken into account in order to exempt the debtor from contractual liability in the event of nonperformance by such party.

40 Tribunal of Bologna, decree of 12 May 2020. 
payment of the rent. The outcome of the temporary judgment has been the same as that of Venice. Eventually, the Tribunal of Genova has addressed the case of the owner of a discotheque who had provided the lessor with a promissory note as a guarantee of the rent, and that could not pay such rent due to the lockdown. ${ }^{41}$ Even in this case, the Tribunal ruled on behalf of the debtor, thus preventing the lessor from enforcing the promissory notes. ${ }^{42}$ In the three cases above, COVID-19 and the consequent lockdown measures were deemed events able to legally affect the ordinary course of the contractual relationship. ${ }^{43}$

Article 1218 of the French Civil Code provides that force majeure justifies suspension or termination of a contract, even if the contract does not contain any provision in that respect. Three conditions must be met for an event to qualify as force majeure: the event must have been beyond the control of the debtor; the event must not have been foreseeable to the parties at the time of the conclusion of the contract; and the event must be unavoidable. If the impossibility to perform the contract is temporary, performance of the obligation is only suspended, unless the resulting delay justifies termination of the contract. If it is permanent, the contract is terminated by operation of law and the parties are discharged from their obligations. In addition, under art 1195 of the French Civil Code (Imprévision), a party to a contract entered into on or after 1 October 2016 may ask their counterparty to renegotiate the contract if a change of circumstances, unforeseeable at the time of the conclusion of the contract, renders performance excessively onerous and if that party did not agree to bear the risks of such a change of circumstances. ${ }^{44}$ If the other party refuses or if the negotiation fails,

41 Tribunal of Genova, decree of 1 June 2020.

42 The three rulings have found juridical ground both in the general contractual provisions of the Italian Civil Code and in the special legislative provisions enacted during the COVID-19 emergency. They reveal a cultural approach to the issue of commercial lease contract opposite to that adopted, for example, by the Hong Kong courts. See above nn 30-32 and relevant text.

43 Lease contracts are particularly notable when dealing with supervening circumstances because, in general, these events do not directly affect the performance of the debtor (ie the pecuniary obligation to pay the rent), which is still possible. Consequently, such cases are usually dealt with as hardship cases where the performance has become excessively burdensome and the equilibrium of the bargain has been dramatically altered. However, the lockdown measures imposing the closure to the public of the premises (whether a shop, a beauty salon or a club) might also be understood as events directly affecting the core of the commercial lease, since they impede the normal destination and availability of the rented spaces. The legislative decree $6 / 2020$ neither refers to impossibility of performance nor to hardship, but generally refers to the compliance with the lockdown measures as an element to be always considered in order to exempt the non-performing party from contractual liability.

44 Public law has recognised the doctrine of imprévision since a judgment of the French Council of State in 1916. The theory is nowadays codified by the Public Procurement Code (PPC), entered into force on 1 April 2019. Article L.6,3 PPC provides that an agreement can be modified when an event "exterior to the parties, unpredictable and temporarily disrupting the balance of the contract" takes place. In this case, the other party is entitled to compensation. In exchange for this, the latter is required to continue to execute the agreement and all the related obligations. 
then the parties may either terminate the contract at a date and under conditions that they agree on, or they can request a judge to adapt the contract to the new circumstances. If the parties do not reach an agreement within a reasonable period of time, then either party may request a judge to revise the contract or to terminate it, at a date and under conditions to be determined by the judge. Pending the negotiation, the parties must keep on performing the contract. ${ }^{45}$ Thus, the French law shows a legislative inclination in favour of the renegotiation by the parties and the judicial intervention, following the development occurred within the model rules and principles for international contracts. $^{46}$

Similarly, through a 2002 reform of the law of obligations, the German legal system formally recognises the doctrine of "foundation of transaction" (Lehre von der Geschäftsgrundlage). Consequently, the Bürgerliches Gesetzbuch (German Civil Code or BGB) now deals specifically with impossibility of performance ( $\$ 275$ BGB) on one side, and unforeseen circumstances affecting the contractual equilibrium $(\$ 313 \mathrm{BGB}),{ }^{47}$ on the other. ${ }^{48}$

The statutory provisions of many Islamic countries provide for the legal effects of supervening events, distinguishing between impossibility of performance, on one side, and change in circumstances ("intervening contingencies") on the other. In addition, Islamic scholars have deemed force majeure and hardship not to be in conflict with the Sharia principles. ${ }^{49}$

45 See generally Pascale Accaoui Lorfing "Article 1195 of the French Civil Code on Revision for Hardship in Light of Comparative Law" (2018) 5 IBLJ 449 (stressing the role of the parties' will in the search of a solution to the change of circumstances in light of the duty to renegotiate, and arguing about the role of the judge in revising the contract).

46 See above nn 67-71 and relevant text.

47 The new provision requires a fundamental change in circumstances upon which a contract was based and that it is unreasonable to hold the party to its (unchanged) duty.

48 For an analysis of the doctrine of the foundation of transaction and the German legal system before the 2002 reform see K Zweigert and H Kötz Introduction to Comparative Law (3rd ed, Clarendon Press, Oxford, 1998) at 218 and following. For an analysis of the current role of the BGB see for example Philip Ridder and MarcPhilippe Weller "Unforeseen Circumstances, Hardship, Impossibility and Force Majeure under German Contract Law" (2014) 22 ERPL 371. See also Dietrich Maskow "Hardship and Force Majeure" (1992) 40 Am J Comp L 657 at 659, arguing that Germany has experienced three waves of great importance in order for the issue of contract's adaptation: first, the phenomenon of inflation post World War I; second, the oil crisis in the 1970s; and third, the collapse of the socialist system.

49 See in particular Abd El-Wahab Ahmed El-Hassan "Freedom of Contract, the Doctrine of Frustration, and Sanctity of Contracts in Sudan Law and Islamic Law" (1985) 1 ALQ 51 (stressing that the statutory provisions of Arab Civil Codes are inspired by the Islamic doctrine of necessity - darura - and excuse - udhr); Mhd Syahnan "Force Majeure in Islamic Law of Transaction: A Comparative Study of the Civil Codes of Islamic Countries" (2013) 9 Tsaqafah 1 (emphasising that the requirement of justice has a predominant role within Islamic law and that it can defeat the binding force of a contract); and Sue Rayner "A Note on Force Majeure in Islamic Law" (1991) 6 ALQ 86 (highlighting that sharia recognises any "act of God" or unforeseen event as coming under the ambit of force majeure, and that force majeure includes any unforeseen change in 
As a general rule, the failure of a party to perform their obligations renders the party liable for such breach, unless they prove that the non-performance was due to force majeure, or to an event beyond their control and not imputable to them. ${ }^{50}$ Generally, the constitutive elements of force majeure are: the event must be unforeseeable ${ }^{51}$ force majeure must be unavoidable; and it must render performance impossible. ${ }^{52}$ Furthermore, the provisions about impossibility of performance are not mandatory; accordingly, parties are entitled to agree upon a different allocation of liabilities and to disregard the statutory provisions or modify them through specific clauses in their contract. Although impossibility of performance and the doctrine of intervening contingencies share certain common features, differences exist between them. The main distinctions are: ${ }^{53}$ (1) in order for an event to be qualified as an intervening contingency, it should affect a number of people (ie it must be general); on the contrary, force majeure can affect even a single contracting party; (2) force majeure renders the performance of the contractual obligation impossible, while intervening contingencies lead to severe hardship only if performance is allowed in its original form; (3) force majeure results in the termination or suspension of the contract, while intervening contingencies allow the courts to modify the terms of the contract; and (4) force majeure does not fall within the domain of "public

circumstances which is outside the control of the obligor, and which, through no fault of the same, may constitute unfair loss or harm to the affected party).

50 See in particular Adnan Amkhan "Force Majeure and Impossibility of Performance in Arab Contract Law" (1991) 6 ALQ 297 at 300 (referring to arts 165, 168, 304, 127 and 233 of the Egyptian, Libyan, Syrian, Yemeni, Algerian, Kuwaiti and Qatari Civil Code, which are respectively identical and provide as follows:

In the absence of a provision of law or an agreement to the contrary, a person is not liable to make reparation, if he proves that the damage occurred from a cause beyond his control, such as cas fortuit, force majeure, the act of the injured party or of a third party.

Articles 211, 261 and 287 of respectively the Iraqi, Jordanian and United Arab Emirates Civil Codes are also identical except that they add the expression "act of God" after force majeure).

51 But with the exception of the Libyan legal system. Indeed, art 218 of the Libyan Civil Code provides:

When specific performance by the debtor is impossible, he will be ordered to pay damages for nonperformance of his obligation, unless he establishes that the impossibility of performance arose from a cause beyond his control. The same principle will apply if the debtor is late in the performance of his obligation.

Pursuant to such a legal system, in order for a party to be released from their contractual obligations and from liability for damages, the event must fulfil the requirements of the Libyan law and the party must not have voluntarily waived the effects of force majeure (for example through a clause which restricts or rules such effects out). However, whilst the event must render the execution of the obligation impossible and not due to the fault of the non-performing party, it needs not be unforeseeable. See Dahmane Ben Abderrhamane "Force Majeure in Libyan Law: Current Issues" (2012) 26 ALQ 387.

52 Amkhan, above n 50, at 301-305.

53 At 308. 
order", as does the principle of intervening contingencies. ${ }^{54}$ As a general rule, when intervening contingencies have not rendered performance impossible, but the contractual obligation has become unreasonably burdensome for a party, that party may plead exemption from liability for nonperformance due to the supervening event. However, the requirements set forth by the legislative provisions must be met. For example, both the United Arab Emirates and Kuwaiti Civil Codes demand that the circumstances be unforeseen and of a public nature, in addition to further requirements. ${ }^{55}$ Should all of them be fulfilled, the judge is entitled, considering all the circumstances and after weighing up the interests of each party, to reduce the oppressive obligation to a reasonable level if justice so requires, and any contrary agreement shall be null and void. ${ }^{56}$ Moreover, the Syrian Supreme Court has ruled that the sanctity of the contract should be subject to considerations of justice, particularly when certain exceptional and unforeseen events materialise. In addition, the Iraqi Supreme Court has explained that: ${ }^{57}$

... the main purpose of the theory of intervening contingencies is to help the aggrieved contracting party to continue performing his contractual obligation; also, to minimize the hardship inflicted upon him by the supervening event. It is important however, [that] the aggrieved party should have been, and still is, performing his obligations according to the terms of the contract and his good faith.

Referring to international contracts, the CISG purposely neither adopts the terminology of any national legal doctrines nor specifically refers to force majeure and/or hardship, ${ }^{58}$ but rather opts in favour of a functional approach. Indeed, art 79, which is included within Section IV dealing with exemptions, provides a description of circumstances whereby the non-performing party is exempted from liability. The text of the provision is built upon the concept of "impediment" which shall be beyond the control of the non-performing party, and the relevant burden of proof is charged upon that

54 See in particular Adnan Amkhan "The Effect of Change in Circumstance in Arab Contract Law" (1994) 9 ALQ 258 .

55 Article 249 of the UAE Civil Code provides that the circumstance be of a public nature, unforeseeable and make performance oppressive for the obligor, so as to threaten such party with serious loss.

56 UAE Civil Code, art 249; and Kuwaiti Civil Code, art 198. See also Rayner, above n 49.

57 For an analysis of both rulings see Syahnan, above n 49, at 8, nn 16-17 and relevant text.

58 See for example Ingeborg Schwenzer "Article 79" in Schlechtriem and Schwenzer: Commentary on the UN Convention on the International Sale of Goods (4th ed, Oxford University Press, Oxford 2016) at 1130. 
party. ${ }^{59}$ The drafting of art 79 has been one of the most controversial. ${ }^{60}$ In particular, during the working sessions of the CISG, the question whether economic difficulties (ie hardship) should give rise to an exemption was highly debated. ${ }^{61}$ Although the Norwegian delegation submitted a proposal to specifically provide for the discharge from liability of the debtor due to a radical change in the circumstances, the proposal was declined. ${ }^{62}$ The wording of art 79 has thus triggered different interpretations. Pursuant to a minority opinion, reference should be made to the subsidiary law, as chosen by the parties or pointed to by the applicable conflict of laws, even though such approach would lead to a great diversity of potentially applicable legal doctrines. ${ }^{63}$ The majority opinion, however, is that, should the event resulting in hardship or force majeure meet the requirements set forth in art 79, it shall be ruled pursuant to it (or alternatively, through the gap filling technique set forth in art 7(2) of the Convention). ${ }^{64}$ Furthermore, art 79(5) specifically provides for that, should an

59 See Peter Schlechtriem and Petra Butler UN Law on International Sales (Springer-Verlag, Berlin, 2009) at [288]. See also Marcel Fontaine "The Evolution of the Rules on Hardship" in Fabio Bortolotti and Dorothy Ufot (eds) Hardship and Force Majeure in International Commercial Contracts: Dealing with unforeseen events in a changing world (ICC, Paris 2018) 11 at [17], stressing that:

... the term impediment has been chosen by drafters to replace the wider term circumstances which was used in the earlier Hague Convention, in the deliberate intent to express the condition for exemption a more restrictive way

and that, in the opinion of some commentators, "the newly chosen term remained imprecise enough to apply not only to force majeure, but also to hardship".

60 See John O Honnold Uniform Law of International Sales Under the 1980 United Nations Convention (3rd ed, Kluwer Law International, Alphen aan den Rijn (The Netherlands), 1999) at 472-495. See also Denis Tallon "Article 79 Commentary" in Cesare Massimo Bianca and Michael Joachim Bonell (eds) Commentary on the International Sales Law: The 1980 Vienna Sales Convention (Giuffrè, Milan, 1987) at 572-575 arguing that:

Thus Art. 79 was elaborated on a variegated background. Significantly, however, the Convention avoided reference to the domestic theories recapitulated above. It developed a system of its own, which in fact results from a slow maturation process that started with ULIS. This autonomy, illustrated by the lack of reference to accepted wording and concepts of domestic laws (force majeure, frustration, impracticability) renders the interpretation of Art. 79 extremely difficult because one cannot resort to these laws as a guide.

61 See for example Brunner, above n 4, at 410.

62 See Ingeborg Schwenzer and Edgardo Muñoz "Duty to renegotiate and contract adaptation in case of hardship" (2019) 24 Unif L Rev 149 at 152, n 22.

63 See CISG Advisory Council Exemption of Liability for Damages Under Article 79 of the CISG (Opinion No 7, 2017), arguing that, although the wording of art 79 refers to "failure of performance" but does not limit the application of such norm to impossibility of performance so that hardship could be included therein, nevertheless the issue is debated and the contrary opinion is properly supported.

64 See Schwenzer and Muñoz, above n 62, at 152-153 (remarking that nowadays "it is more or less unanimously accepted in court and arbitral decisions, as well as in scholarly writings, that Article 79 of the CISG does cover hardship situations. Accordingly, first and foremost, there is no necessity to resort to domestic concepts of hardship as there is no gap in the CISG regarding the debtor's invocation of economic impossibility" 
impediment meeting the requirements set forth in this norm occur, "[n]othing in this article prevents either party from exercising any right other than to claim damages under this Convention". Even such provisions have provoked different opinions. According to some authors, remedies such as the duty to renegotiate, as well as the remedies of contract adaptation and/or termination by a court or an arbitral tribunal, are neither necessary nor desirable under current trade practice and dispute resolution methods. On the contrary, the traditional remedies, such as exemption from damages, duty to mitigate loss and/or avoidance of contract by a party's declaration, may serve more adequately the interest of contracting parties in hardship scenarios. Consequently, the wording of art 79 and the remedies set out in the CISG would be satisfactory to deal with hardship issues. ${ }^{65}$ This opinion has been criticised by those who argue that the remedies provided in art 79 CISG are adapted to force majeure situations, but not to hardship circumstances, and that the wording of the provision could not be stretched to cover hardship cases. Accordingly, the supporters of this view argue that force majeure and hardship require different regimes, as attested in contractual practice, in the drafting of different model clauses, and in the codifications of international principles like the UNIDROIT Principles. ${ }^{66}$

However, according to art 6 CISG, had the parties specifically addressed force majeure and/or hardship through a clause in their contract, the will of the parties prevails.

Under the UNIDROIT Principles, force majeure and hardship are provided for separately. In particular, hardship is dealt with in ch 6, s 2, which encompasses three articles (arts 6.2.1-6.2.3). For our purposes, the rule set forth in art 6.2.1 ("[c]ontract to be observed") is significant because it stresses the importance of the pacta sunt servanda maxim, and the exceptional nature of hardship:

Where the performance of a contract becomes more onerous for one of the parties, that party is nevertheless bound to perform its obligations subject to the following provisions on hardship.

To the contrary, pursuant to Official Comment 2 of the article, supervening circumstances, in order to allow the application of hardship, must lead to a fundamental alteration of the equilibrium of

(footnotes omitted)). See also Anna Veneziano "UNIDROIT Principles and the CISG: Change of Circumstances and Duty to Renegotiate according to Belgian Supreme Court" (2010) 15 Unif L Rev 137 at 142 (commenting on the decision of the Belgian Supreme Court, Scafom International BV v Lorraine Tubes SAS SC C.07.0289.N, 19 June 2009, dealing with the possible interaction between UNIDROIT Principles and the CISG through the art 7(2) provision as for hardship issues, and arguing that "the UNIDROIT Principles may play a role in clarifying which general principles could be considered part of CISG in the light of the development of international trade law"). See further Schlechtriem and Butler, above n 59, at [48].

65 See Schwenzer and Muñoz, above n 62, at 160 and following. See also Ndubuisi Nwafor "Doctrinal Watershed in the Interpretation of Contractual Impossibility under the CISG, UNIDROIT Principles and English Law" (2017) 38(6) Bus L Rev 219 at 221 (arguing that art 79 CISG deals with what has been labelled in the national sales law as force majeure, impossibility, frustration, impracticability or hardship, and highlighting that under the CISG doctrine of exemption, "the contract is not automatically discharged as sundry remedies except liability in damages can conveniently apply").

66 See Fontaine, above n 59, at [18]. 
the contract, so to create an exceptional situation. On the other side, force majeure is provided for by UNIDROIT Principles in art 7.1.7, under the chapter devoted to "[n]on-performance". However, since the distinction between hardship and force majeure is not always so feasible, the UNIDROIT Principles adopt a functional approach, and highlight in an Official Comment that: ${ }^{67}$

... under the Principles there may be factual situations which can at the same time be considered as cases of hardship and of force majeure. If this is the case, it is for the party affected by these events to decide which remedy to pursue. If it invokes force majeure, it is with a view to its non-performance being excused. If, on the other hand, a party invokes hardship, this is in the first instance for the purpose of renegotiating the terms of the contract so as to allow the contract to be kept alive although on revised terms

Consequently, it will up to the non-performing party to invoke either force majeure or hardship in light of the pursued remedy. Generally, should a force majeure event occur, the contract is terminated (or its effects suspended in case of temporary impossibility to perform). ${ }^{68}$ On the contrary, in case of hardship the UNIDROIT Principles provide for three different remedies: renegotiation by the parties of the contractual terms (which is not mandatory); termination of the contract; or judicial adaptation of the contract. Pursuant to art 6.2.3, when the requirements for hardship are met:

(1) In case of hardship the disadvantaged party is entitled to request renegotiations. The request shall be made without undue delay and shall indicate the grounds on which it is based. (2) The request for renegotiation does not in itself entitle the disadvantaged party to withhold performance. (3) Upon failure to reach agreement within a reasonable time either party may resort to the court. (4) If the court finds hardship it may, if reasonable, (a) terminate the contract at a date and on terms to be fixed, or (b) adapt the contract with a view to restoring its equilibrium.

67 UNIDROIT Principles, above n 2, art 6.2.2, Official Comment 6; and art 7.1.7, Official Comment 3. See Ugo Draetta "Hardship and Force Majeure Clauses" [2002] IBLJ 347 regarding the difficulty of distinguishing the two concepts.

68 According to the force majeure provision in art 7.1.7:

(1) Non-performance by a party is excused if that party proves that the non-performance was due to an impediment beyond its control and that it could not reasonably be expected to have taken the impediment into account at the time of the conclusion of the contract or to have avoided or overcome it or its consequences. (2) When the impediment is only temporary, the excuse shall have effect for such period as is reasonable having regard to the effect of the impediment on the performance of the contract. (3) The party who fails to perform must give notice to the other party of the impediment and its effect on its ability to perform. If the notice is not received by the other party within a reasonable time after the party who fails to perform knew or ought to have known of the impediment, it is liable for damages resulting from such non-receipt. (4) Nothing in this Article prevents a party from exercising a right to terminate the contract or to withhold performance or request interest on money due. 
However, the latter provision does not restate the settled practices of the international business community, but rather is the outcome of a specific choice made by the drafters of the UNIDROIT Principles. ${ }^{69}$ Indeed, the judicial power to alter the original terms of the contract is highly controversial. Hence, it is quite common for parties to an international contract when choosing the UNIDROIT Principles as applicable law, to rule out some articles therein, in particular those about hardship (and specifically art 6.2.3). ${ }^{70}$ They can be substituted by a clause negotiated by the parties, or by the ICC model clause on hardship (again, with the tendency to exclude the option entitling the judge or the arbitrator to adapt the contract). The ICC model clause on hardship, on the declared assumption that the judicial intervention is highly controversial, purposely allows the parties to choose among three different alternatives: ${ }^{71}$ (a) should the renegotiation fail, the party invoking the hardship is entitled to terminate the contract; (b) should the renegotiation fail, either party is entitled to request the judge or the arbitrator to adapt the contract or to terminate it; or (c) should the renegotiation fail, either party is entitled to request the judge or the arbitrator to declare the termination of the contract.

The ICC force majeure clause provides with a general definition followed by a list of events typically qualified as force majeure. The general definition is grounded on "reasonableness": the nonperformance must be due to an impediment beyond the reasonable control of the affected party; the impediment could not reasonably have been foreseen at the time of the conclusion of the contract; and the effects of the impediment could not reasonably have been avoided or overcome by the affected party. ${ }^{72}$

Despite the peculiarities of every model, the comparison reveals a common core of rules. First, the pre-eminence of the pacta sunt servanda principle, in order to ensure certainty and predictability of contractual obligations. Second, the event (or its effects) must occur after the formation of the contract. Third, the event must be unpredictable ${ }^{73}$ and beyond the party's control. Fourth, the affected

69 See "Final 8873" (1999) 10(2) ICC Int'l Ct Arb Bull at 81 and following, stating that the UNIDROIT Principles on hardship: "ne correspondent pas, au moins à l'état actuel, à la pratique courante des affaires dans le commerce international".

70 Fabio Bortolotti Il Contratto Internazionale (2nd ed, Cedam, Padua (Italy), 2017) at 285-286.

71 ICC ICC Force Majeure and Hardship Clauses (March 2020):

Since one of the most disputed issues is whether it is appropriate to have the contract adapted by a third party (judge, arbitrator) in case the parties are unable to agree on a negotiated solutions, the clause provides two options between which the parties must choose: adaptation or termination.

72 Thus, as highlighted by the ICC itself, the definition of force majeure provides a lower threshold for invoking the clause than impossibility of performance.

73 However, with the exception of the Libyan Civil Code. For commercial impracticability, Official Comment 1 to UCC § 2-615 describes the event as an "unforeseen supervening circumstance not within the contemplation of the parties at the time of contracting". The Comment uses the term "unforeseen", which must be distinguished from "unforeseeable". According to the commonly accepted interpretation, an event is 
party must not be in default. Fifth, there must be a causal link (either direct or even indirect) between the non-performance or the alteration of the contractual equilibrium and the invoked event. As for the remedies, a general approach provides that, when performance becomes impossible (or impracticable) and all the requirements are met, the contract is terminated and the obligations discharged, with no liability upon the affected party. On the contrary, in case of hardship the remedies differ. However, it can be highlighted: (i) a general inclination towards the renegotiation of the contractual terms (though this is neither compulsory nor enforceable); or (ii) the termination of the contract. The judicial or arbitral power to adapt the terms of the contract is highly controversial so model clauses leave the parties free to opt out of a provision.

The general favour towards the renegotiation of the contractual terms is testified not only by the provisions of the UNIDROIT Principles and the ICC hardship clause. For example, the European Law Institute $(\mathrm{ELI})^{74}$ has outlined specific recommendations aimed at dealing with the COVID-19 outbreak. ${ }^{75}$ Among them, the Principle 13(2) suggests that:

Where, as a consequence of the COVID-19 crisis and the measures taken during the pandemic, performance has become excessively difficult (hardship principle), including where the cost of performance has risen significantly, States should ensure that, in accordance with the principle of good faith, parties enter into renegotiations even if this has not been provided for in a contract or in existing legislation.

Finally, the comparative analysis reveals a further common feature: the pre-eminent role granted to party autonomy. Every legal system and model clause entitles contracting parties to agree on the allocation of risk related to supervening events through ad hoc clauses. ${ }^{76}$ Should this be the case, the negotiated legal framework would prevail. This phenomenon becomes particularly significant in the context of international commercial contracts and must not be neglected by the parties. Indeed, as already stressed, particular attention must be given to the drafting and the specific wording of such

unforeseen by the parties if they did not contemplate it as a real likelihood. Whilst an event is deemed "unforeseeable" if it could not have been conceived of by a reasonable person.

74 The European Law Institute (ELI) is an independent non-profit organisation established to provide practical guidance in relation to European legal development. See further European Law Institute <www.european lawinstitute.eu>.

75 The Author wishes to thank both the SIRD (Società Italiana per la Ricerca nel Diritto) and Professor Pietro Sirena for having made the draft available to the members of the former before its official publication.

76 Particular emphasis on this option is given by the second part of the Restatement, above $\mathrm{n} 14$, note to ch 11:

The obligor who does not wish to undertake so extensive an obligation may contract for a lesser one by using one of a variety of common clauses: he may agree only to use his 'best efforts'; he may restrict his obligation to his output or requirements; he may reserve a right to cancel the contract; he may use a flexible pricing arrangement such as a "cost plus" term; he may insert a force majeure clause; or he may limit his damages for breach. 
clauses, since the judicial scrutiny would be focused on the contractual terms in light of the governing law of that contract. ${ }^{77}$

COVID-19 can qualify by itself as a natural calamity in all the legal models. However, a distinction must be made between COVID-19 as a disease and health emergency, that falls within the concept of act of God, and the governmental regulations made to prevent the diffusion of the outbreak through containment and lockdown measures, that belong to the category of Act of King, or factum principis. $^{78}$

For example, since January 2020 the China Council for the Promotion of International Trade has issued more than 5600 certificates attesting "force majeure" on behalf of companies that have failed to comply with the obligations of international contracts, allegedly due to the COVID-19. ${ }^{79}$ In India, an Office Memorandum of the Ministry of Finance dated February 19, 2020 has declared that the disruption of the supply chain as a result of the COVID-19 outbreak constitutes a force majeure event. In particular, the Memorandum clarifies that COVID-19 should be considered "a case of natural calamity". The aim is the same although the technique differs. In China the CCPIT has issued certificates for every eligible company; in India there has been a general public statement on behalf of all the enterprises belonging to an economic sector. Though such official statements and certificates would be evidence that a particular event occurred, they would be insufficient to fulfil the requirements of a force majeure clause without evidence that the non-performance was caused by that event. Indeed, although COVID-19 and the connected governmental regulations fall respectively within the category of act of God and act of King, and though both can in principle be qualified as force majeure or an intervening contingency able to affect the equilibrium of the bargain, nevertheless all the legal systems require that additional constitutive elements are met. ${ }^{80}$ Consequently, COVID19 as a disease and the governmental regulations to prevent its diffusion, are not enough on their own to discharge the non-performing party from liability. In a further example, the First Civil Division of the Higher People's Court of Zhejiang Province has issued a notice stating that force majeure can be

77 See Tandrin Aviation Holdings Ltd v Aero Toy Store LLC [2010] EWHC 40 (Comm), [2011] 2 Lloyd's Rep 668 which highlighted that, where a clause contains a non-exclusive list of events, followed by general language such as "any other cause beyond the party's control", in order for an event to fit within this general wording, it must be of a similar nature to the specific events listed.

78 The distinction matters because the governmental regulations are commonly enacted after a period of time from the appearing of the epidemic. Consequently, there will be a gap between the occurrence of the natural calamity and the enactment of the lockdown provisions. The position of the party towards their contractual obligations shall be assessed considering such gap and the justification invoked for their non-compliance. Indeed, many legal systems, in order to excuse a party, require that the party was not in default when the impediment to the performance occurred.

79 See China Council for the Promotion of International Trade (CCPIT) "CCPIT News" <http://en.ccpit.org>.

80 All the legal systems require a causal link (either direct or indirect) between the supervening event and the impossibility to perform or the alleged significant alteration of the contractual equilibrium. 
affirmed, provided that: (i) the failure to perform is directly caused by the administrative measures adopted by the Public Authorities to prevent the COVID-19 outbreak; or (ii) the party could not perform their contractual obligations because they were directly affected by the COVID-19 disease. ${ }^{81}$ In both cases, the burden of proof is borne by the non-performing party. Similarly, on 16 April 2020 the China's Supreme People's Court published its Guiding Opinions (I) on Several Issues concerning the Proper Trial of Civil Cases Related to the Novel Coronavirus Pneumonia (COVID-19). ${ }^{82}$ The Court stresses a number of key considerations in applying force majeure and related principles to relieve contract parties from liability for contract performance where performance is impacted either by the COVID-19 pandemic itself or government measures taken to control it. In particular, the party seeking to be discharged in whole or in part from a civil liability due to force majeure must demonstrate: (a) causation (including its extent) between the pandemic or related control measures and the party's failure to perform; and (b) that they provided timely notice to the other party. In addition, if the party invoking force majeure contributed to the failure to perform or to the extent of losses suffered, it should bear legal responsibility for its contribution. ${ }^{83}$ Such approach seems consistent with the depicted comparative scenario.

A final remark is that the legal consequences of COVID-19 and the related governmental provisions for international contracts, as above described, apply to pending contracts. However, with reference to international contracts entered into after the occurrence of such phenomena, or still to be formed, the requirement of the unpredictability of the event could not be successfully invoked. Consequently, it will be up to the contracting parties to properly provide for such occurrences in their contracts in light of the particular features of the contracts and their legal regime.

\section{THE ISSUE OF "OVERRIDING MANDATORY PROVISIONS"}

A highly debated matter is whether the legislative provisions enacted by the governments of countries affected by COVID-19 in order to prevent its spreading, can be deemed to be "overriding

81 See Molly Luo and Limeng Yang "COVID-19 and Force Majeure in China" (2 March 2020) R\&P Lawyers <www.rplawyers.com>. Such an initiative is of particular relevance because the Zhejiang's economy is dominated by small and medium-sized enterprises (SMEs) which are family-owned and have no settled corporate governance structure. Zhejiang is one of the two most litigious provinces in China, and this is probably due to its fragmented economy. For further economic and statistics information see: Mingxing Liu and others "The informal power configuration of local government and economic development policy in China" (2015) 2(6) The Journal of Chinese Sociology 1; and Qi Zhang and Mingxing Liu" The Political Economy of Private Sector Development in Communist China: Evidence from Zhejiang Province" (2013) 48 St Comp Int Dev 196.

82 On the role of the Supreme People's Court in interpreting the law and providing guidelines to other courts see for example Taisu Zhang "The Pragmatic Court: Reinterpreting the Supreme People's Court of China" (2012) 25 Colum J Asian L 1; and Susan Finder "The Supreme People's Court of the People's Republic of China" (1993) 7 J Chinese L 145.

83 See Morrison Foerster "China's Supreme People's Court Issues Long-awaited Guidance on COVID-19 Related Civil Disputes" (22 April 2020) <www.mofo.com/resources/insights>. 
mandatory provisions" (otherwise known as "international mandatory provisions") for the purposes of the private international law. ${ }^{84}$ Overriding mandatory provisions are those rules of a legal system that must be applied even when the international contract is governed by a different law. Their legal rationale lies in the will of a country to ensure that every international contract, with a particular connection with its own legal system, conform with those specific rules. Generally, their overriding mandatory nature can be expressly or impliedly affirmed by the legal system. However, absent an explicit statement, it will be up to the judge to consider their legal force, and whether they have overriding mandatory effect.

The concept and an attempted definition of such rules can be found in art 9 of the Regulation (EC) No 593/2008 of the European Parliament and of the Council of 17 June 2008 on the law applicable to contractual obligations (Rome I Regulation): ${ }^{85}$

Overriding mandatory provisions are provisions the respect for which is regarded as crucial by a country for safeguarding its public interests, such as its political, social or economic organization, to such an extent that they are applicable to any situation falling within their scope, irrespective of the law otherwise applicable to the contract under this Regulation.

A further definition on the law applicable to contractual obligations can be found in art 7 of the Regulation 80/934/EEC: Convention on the law applicable to contractual obligations opened for signature in Rome on 19 June 1980 (1980 Rome Convention): ${ }^{86}$

When applying under this Convention the law of a country, effect may be given to the mandatory rules of the law of another country with which the situation has a close connection, if and in so far as, under the law of the latter country, those rules must be applied whatever the law applicable to the contract. In considering whether to give effect to these mandatory rules, regard shall be had to their nature and purpose and to the consequences of their application or non-application.

84 There is not a common expression for these rules. Pursuant to the English version of the Rome I Regulation, above $\mathrm{n} 10$, they are named "overriding mandatory provisions", while the French version uses the expression "lois de police", the Italian version refers to them as "norme di applicazione di necessaria", the German version uses the term "Eingriffsnormen" and the Spanish version refers to them as "leyes de policia". Under the 1980 Rome Convention, below n 86, on the law applicable to contractual obligations, they are named "(international) mandatory provisions".

85 Article 9(1)

86 Regulation 80/934/EEC: Convention on the law applicable to contractual obligations opened for signature in Rome on 19 June 1980 [1980] OJ L266/1 [1980 Rome Convention], art 7(1). 
Examples of overriding mandatory rules are the legislative provisions of Belgium and Finland setting forth a regime to protect the interests of the agent in an agency agreement and granting the agent the right to a specific pecuniary indemnity, should the contract be terminated. ${ }^{87}$

The power of a state to qualify as overriding mandatory provisions certain rules of its own legal system for the purposes of the international private law, and their legal effects in an international scenario, have been also addressed by the European Court of Justice in the case of Unamar $v$ Navigation Maritime Bulgare. ${ }^{88}$ In particular the ECJ affirmed that the Belgian provisions dealing with agency contract are overriding mandatory provisions to be applied to the international contract despite its governing law. However, it must be highlighted that the dispute in that case was to be solved by the Belgian courts.

Indeed, some countries have specifically provided for the legal consequences of the national lockdown measures, in particular mandating that the non-performance of a contractual obligation due to such provisions and to the COVID-19 outbreak amounts to a force majeure case, therefore discharging the affected party from their contractual obligations and from the related liabilities. ${ }^{89}$ Alternatively, the national statutory provisions set forth a mandatory legal regime for the consequences of COVID-19 providing that, for example, the damaged party is entitled to certain contractual remedies but is prevented from benefiting from others. ${ }^{90}$ The question is whether these national provisions are legally binding and effective with reference to international contracts governed

87 See in particular the Belgian Law of 13.04.1995; and the Finnish Law of n 417/1992 art 2, para 2 about agency contract. See also the Belgian Law of 27.07.1961 on the concession de vente exclusive (exclusive sales concession).

88 Case C-184/12 Unamar v Navigation Maritime Bulgare [2014] 1 Lloyd's Rep 161 (CJEU). For a comment of the ruling see Fabio Bortolotti "EU: Law applicable to agency agreements - the UNAMAR v. Navigation Maritime Bulgare case (Judgment of the European Court of Justice of 17 October 2013)" (16 January 2014) International Distribution Institute <www.idiproject.com>.

89 For example, the above-mentioned certificates issued by the China Council for the Promotion of International Trade or the official statement of the Indian Ministry of Finance.

90 See for example art 4 of the French Ordinance n 2020-306, 25 March 2020. See also art 6-bis of the Italian Law Decree n 6, 23.02.2020, converted in Law Decree n 13, 5.03.2020, as amended by art 91 of the Law Decree n 18, 17.03.2020, according to which compliance with governmental containment measures shall be always considered for the purposes of releasing the debtor from its obligations and contractual liabilities, even with reference to penalty clauses or delayed or omitted payments. Such provision applies to contracts in general. On the contrary, with specific reference to the purchase of package travel and linked travel arrangements, see art 28 of the Italian Law Decree n 9, 2.03.2020, dealing with the reimbursement of such purchases. In particular, contractual parties are discharged from their obligations due to the COVID-19 force majeure, and traders are entitled to reimburse the purchasers through, at their will, restitution of the money or issuance of a voucher to be used within one year. Paragraph 8 of the present statutory provision expressly qualifies it as "international mandatory provision" for the purposes of both the Italian conflict of law system (ie Law Decree 218/1995) and art 9 of the Rome I regulation (see above nn 85-86 and relevant text). 
by a different law. In other words, it is debatable whether these national provisions can be deemed to be overriding mandatory provisions for the purposes of private international law.

When dealing with the current issue, two different cases must be distinguished between. First, if the dispute about the international contract is to be decided by a judge of the legal system with the alleged overriding mandatory provisions. Second, whether a judge of a different country or an arbitral tribunal is entitled to resolve the dispute..$^{91}$

In the first case, it is highly probable (almost certain) that the national judge will affirm the overriding mandatory legal effects of the provisions of their national legal system, whilst it seems less probable in the second case. In the second case, the judge and/or the arbitrator will be entitled to assess whether to apply the governing law of the contract, disregarding the alleged overriding mandatory provisions, or not. ${ }^{92}$ Moreover, the application of such rules becomes an issue only when the international contract shows a qualified connection with that particular legal system. ${ }^{93}$ Consequently, if such requirement is not fulfilled or the judge/arbitral tribunal decides not to apply the alleged overriding mandatory provisions in light of other reasons, the dispute will be decided on the basis of the governing law of the international contract. In this case, a different issue may arise, namely whether the holding or the arbitral award might be recognised and enforced in the country of the mandatory overriding provisions, due to the potential conflict with the public order of that country. ${ }^{94}$

91 According to arts 9.2 and 9.3 of the Rome I Regulation:

... 2. Nothing in this Regulation shall restrict the application of the overriding mandatory provisions of the law of the forum. 3. Effect may be given to the overriding mandatory provisions of the law of the country where the obligations arising out of the contract have to be or have been performed, in so far as those overriding mandatory provisions render the performance of the contract unlawful. In considering whether to give effect to those provisions, regard shall be had to their nature and purpose and to the consequences of their application or non-application.

See also art 7.2 of the 1980 Rome Convention, above $n$ 86:

Nothing in this Convention shall restrict the application of the rules of the law of the forum in a situation where they are mandatory irrespective of the law otherwise applicable to the contract.

92 Both art 9.3 of the Rome I Regulation and art 7.1 of the 1980 Rome Convention stress the judicial discretion about the application of such provisions adopting the same wording:

In considering whether to give effect to those provisions, regard shall be had to their nature and purpose and to the consequences of their application or non-application.

93 Pursuant to art 9 of Rome I, above n 10 and to art 7 of the 1980 Rome Convention, above n 86.

94 Indeed, pursuant to the Convention on the Recognition and Enforcement of Foreign Arbitral Awards 330 UNTS 3 (signed 10 June 1958, entered into force 7 June 1959), if the requirements for the application of the convention are fulfilled, the national competent authorities are obliged to recognise and enforce the arbitral award, subject to specific exceptions set forth in art 5. Among these exceptions there is the case whereby: "[t]he recognition or enforcement of the award would be contrary to the public policy of that country" (art 5(2)(b)). However, to preserve the effectiveness of the Convention, the concept of "public policy" must be 
In light of such remarks, it does not seem that the provisions enacted by the states affected by the COVID-19 outbreak, even when expressly qualified as overriding mandatory provisions for the purposes of the international private law, will be ipso jure applied in case of a dispute, especially in the field of international business contracts. ${ }^{95}$ Again, should the dispute be decided by the judge of that country, it is almost certain that the judge will apply such rules to the contract despite a different governing law. However, should the dispute be decided by a judge of a different country or through arbitration, the application of those provisions is subject to the discretionary assessment of the judge/arbitrator, on the basis of the circumstances of the case, and taking into account the will of the parties in setting out the specific governing law of their international B2B contract.

construed narrowly. See generally Jonathan Hill "The Exercise of Judicial Discretion in Relation to Applications to Enforce Arbitral Awards Under the New York Convention 1958" (2016) 36 Oxford J Leg St 304. For a selection of international case law on public policy see also Bortolotti, above $n$ 70, at 132-133.

95 Generally, rules qualified as overriding mandatory provisions are aimed at protecting the weaker party of a contract, like in the case of the agency agreement or consumer contracts. On the contrary, it seems difficult to hold the overriding mandatory nature of provisions that shall be applied to B2B contracts. 